\title{
Diet uniformity at an early farming community in northwest Anatolia (Turkey): carbon and nitrogen isotope studies of bone collagen at Aktopraklık
}

\author{
Chelsea Budd $^{1}$ • Necmi Karul ${ }^{2}$ - Songül Alpaslan-Roodenberg ${ }^{3}$ - Alfred Galik ${ }^{4,5}$. \\ Rick Schulting ${ }^{1} \cdot$ Malcolm Lillie $^{6}$
}

Received: 21 December 2016 / Accepted: 21 June 2017

(C) The Author(s) 2017. This article is an open access publication

\begin{abstract}
Aktopraklik is a settlement site composed of three areas $(\mathrm{A}-\mathrm{C})$ in the Marmara region of northwest Anatolia, with phases of occupation that date to the Late Neolithic and Early Chalcolithic periods, mid-seventh to mid-sixth millennium BC (ca. 6400-5600 cal. BC). Here, we present 54 human and fauna bone collagen stable isotope results from the site, alongside five modern fish bone collagen isotope results, to examine the nature of human diet. The stable isotope analysis shows that human diet comprised the consumption of select $\mathrm{C}_{3}$ terrestrial resources, with a preference for domestic animal proteins over plant proteins. The evidence to date suggests that animal husbandry was at the forefront of Late Neolithic and Early Chalcolithic subsistence practices. No isotopic difference in humans is observed between biological sex or between areas B and $\mathrm{C}$ at the settlement.
\end{abstract}

Electronic supplementary material The online version of this article (doi:10.1007/s12520-017-0523-4) contains supplementary material, which is available to authorized users.

Chelsea Budd

chelsea.budd@bioarch.co.uk

1 School of Archaeology, University of Oxford, 36 Beaumont Street, Oxford OX1 2PG, UK

2 Prehistory Department, University of Istanbul, Istanbul, Turkey

3 Santpoort-Noord, The Netherlands

4 Austrian Archaeological Institute, Austrian Academy of Sciences, Franz-Kleingasse 1, 1190 Vienna, Austria

5 Austria \& Institute for Anatomy, Histology and Embryology, Veterinärplatz 1, 1210 Vienna, Austria

6 School of Environmental Sciences: Geography, University of Hull, Hull HU6 7RX, UK
Keywords Neolithic $\cdot$ Anatolia $\cdot$ Turkey $\cdot$ Stable carbon and nitrogen isotopes $\cdot$ Palaeodietary reconstruction

\section{Introduction}

Understanding the process of Neolithization in western Anatolia is important, as it is often considered as the 'jumping off point' for the transmission of the Neolithic package from Central Anatolia and the Levant into the Balkans, the Aegean, and ultimately further beyond into mainland Europe (Roodenberg 2016). Recent genomic-wide data sampled from Neolithic Anatolian human bone samples has provided a persuasive argument that members of Anatolian communities formed part of the source population of Europe's first farmers (Lazaridis et al. 2014; Mathieson et al. 2015). Multi-region zooarchaeological work provides convincing evidence that places the origins of western Eurasian domesticates (e.g. sheep, goats, cattle, and pigs) in the Fertile Crescent (Peters et al. 2014; Arbuckle and Atici 2013; Vigne et al. 2012; Zeder 2011). These recent studies, integrated within the existing framework of research for Neolithic Anatolia, provide evidence for a clear transmission of people and of livestock from the Fertile Crescent into western Turkey and beyond.

In the last decade, there has been fluctuating debate surrounding the nature of subsistence practices in Neolithic northwest Anatolia (Arbuckle et al. 2014; Thissen et al. 2010; Çilingiroğlu and Çakırlar 2013). Previous studies have evaluated the implications of considerable quantities of aquatic remains at coastal sites such as Fikirtepe and Pendik, with further research of pottery residue analysis at contemporary sites in the region, including Barcın Höyük, Așağı Pınar, Toptepe, Yarımburgaz, Fikirtepe, Hoca Çeşme, and Pendik, producing emphatic results for extensive dairying in 
northwest Anatolia (Thissen et al. 2010; Türkekul-Biy1k and Özbal 2008; Evershed et al. 2008). Currently, the most persuasive arguments have emerged from zooarchaeology studies that utilize online data-sharing approach to examine subsistence methods across Anatolia (Arbuckle et al. 2014). The study provides compelling evidence to support a westward expansion of Neolithic subsistence economies that combined multiple routes and pulses and did not include a uniform 'package' of livestock domesticates (Arbuckle et al. 2014:1). At Aktopraklık, sheep, goat, and cattle dominate the faunal assemblage, with the evidence for domestic pigs appearing only sporadically in the archaeological record. Fallow deer are recovered in higher quantities from the Neolithic and Chalcolithic phases at Aktopraklık than domestic pigs (Galik et al., personal communication).

At Aktopraklık, the phases of occupation date from the mid-seventh to mid-sixth millennia (i.e. Late Neolithic and Early Chalcolithic, respectively), with evidence for occupation spread over three areas (i.e. sites A-C). The aim of this paper is to examine the nature of diet at Aktopraklık, investigating differences in diet between sex and also between locations with burials (Aktopraklık B and Aktopraklık C). This study investigates human and faunal bone collagen from the Neolithic (ca. 6400-6000 cal. BC) and Chalcolithic (ca. 59005750 cal. BC) periods.

Aktopraklık $\mathrm{C}$ is characterized by the presence of round Late Neolithic building structures, Late Neolithic and Early Chalcolithic graves, alongside Late Roman building structures. Aktopraklık B dates to the Early Chalcolithic (both settlement and burials), and witnesses the introduction of rectangular mud-brick structures with surrounding ditches. There are small differences in burial goods between humans excavated from Aktopraklık B and those from Aktopraklık C. This study examines the nature of diet at the site, and aims to disentangle the relative contributions of animal proteins and plant proteins in human diet at Aktopraklık. Additionally, this paper investigates the isotopic information to examine whether there is any difference in dietary isotopes between humans interred at Aktopraklık $\mathrm{C}$ and humans interred at Aktopraklık $\mathrm{B}$. There is a change in the type of building structures observed at the site areas. Aktopraklık $\mathrm{C}$ is characterized by wattle and daub structures and the structures at Aktopraklik $\mathrm{B}$ transition into rectangular mud-brick houses with a systematic layout (Karul 2011; Karul and Avci 2013). Aktopraklık B is also characterized by the presence of impresso-cardium pottery.

The data will also be used to examine possible isotope differences between individuals of differing biological sex at the site. The study is addressed through the application of stable carbon and nitrogen isotope analysis of bone collagen. Human, domestic fauna, and wild fauna bone collagen from the Neolithic and Chalcolithic layers of the site were analysed, alongside modern fish (bone collagen) species from the nearby freshwater Lake Uluabat. Modern aquatic species were analysed to investigate the possible inclusion of freshwater aquatic proteins with reference to their presence at earlier Neolithic sites in northwest Anatolia (for overview, see Çakırlar 2014, 2015; Arbuckle et al. 2014). Admittedly, the presence of Lake Uluabat during the seventh/sixth millennium does not appear to be securely attributed in the literature, with palynological evidence from limnological cores radiocarbon dated to $3200 \mathrm{BP}$ (Bottema and Woldring 2001), and studies of sedimentation rates producing similar chronological data (Kazanc1 et al., 2004, Kazanc1 et al., 2006). The origin of Lake Uluabat (in addition to the 'sister' lakes which also form part of the Susurluk Drainage Basin) is thought to have formed via channel damming of a meandering stream system, possibly during a period of mid-Holocene sea level increase (Emre et al. 1997; Leroy et al. 2002). Therefore, the question of the definitive presence of the lake during the study period remains unanswered. However, as aquatic skeletal remains were uncovered from the nearby site of Ilipınar (including carp and Pisces sp. and freshwater mussels), this study analyses isotope values of modern fish samples from Lake Uluabat in order to test all potential dietary sources. The use of modern fish bones, from a slightly further away site, is admittedly not ideal, but in the absence of other data, it is a useful comparative archive. This paper presents the final cohort of carbon and nitrogen isotope values of skeletal collagen for this project, with the results from the first isotopic study present in the literature (Budd et al. 2013).

\section{Site and background}

Originally discovered in 2002 during archaeological survey, Aktopraklık is located on the southern shore of the Marmara Sea, and its archaeological evidence suggests a fully formed agricultural society that includes the earliest evidence for Neolithic monochrome pottery in the region (Karul 2007; Karul and Avc1 2011).

The site location - close to an extinct river course and an extant spring and on a level raised area on the shores of (potentially) Lake Uluabat-would suggest that during the Neolithic and Chalcolithic periods, the occupants of the site were ideally situated to exploit both freshwater and saltwater resources and the adjacent forest zone (Karul and Avc1 2011:2) (Fig. 1).

There are two accelerator mass spectrometry (AMS) dates for the human bone at Aktopraklık, with a Neolithic interment (individual 89D-4.4-06) placed at ca. 6400-6235 cal. BC (OxA-20596) and an early Chalcolithic burial (individual 88E-12.1-07) placed at 5736-5635 cal. BC (OxA-20597) (Budd et al. 2013:862). Overall, the two dates appear to correspond with the dating established at other settlements in the eastern Marmara region, being commensurate with the earliest 


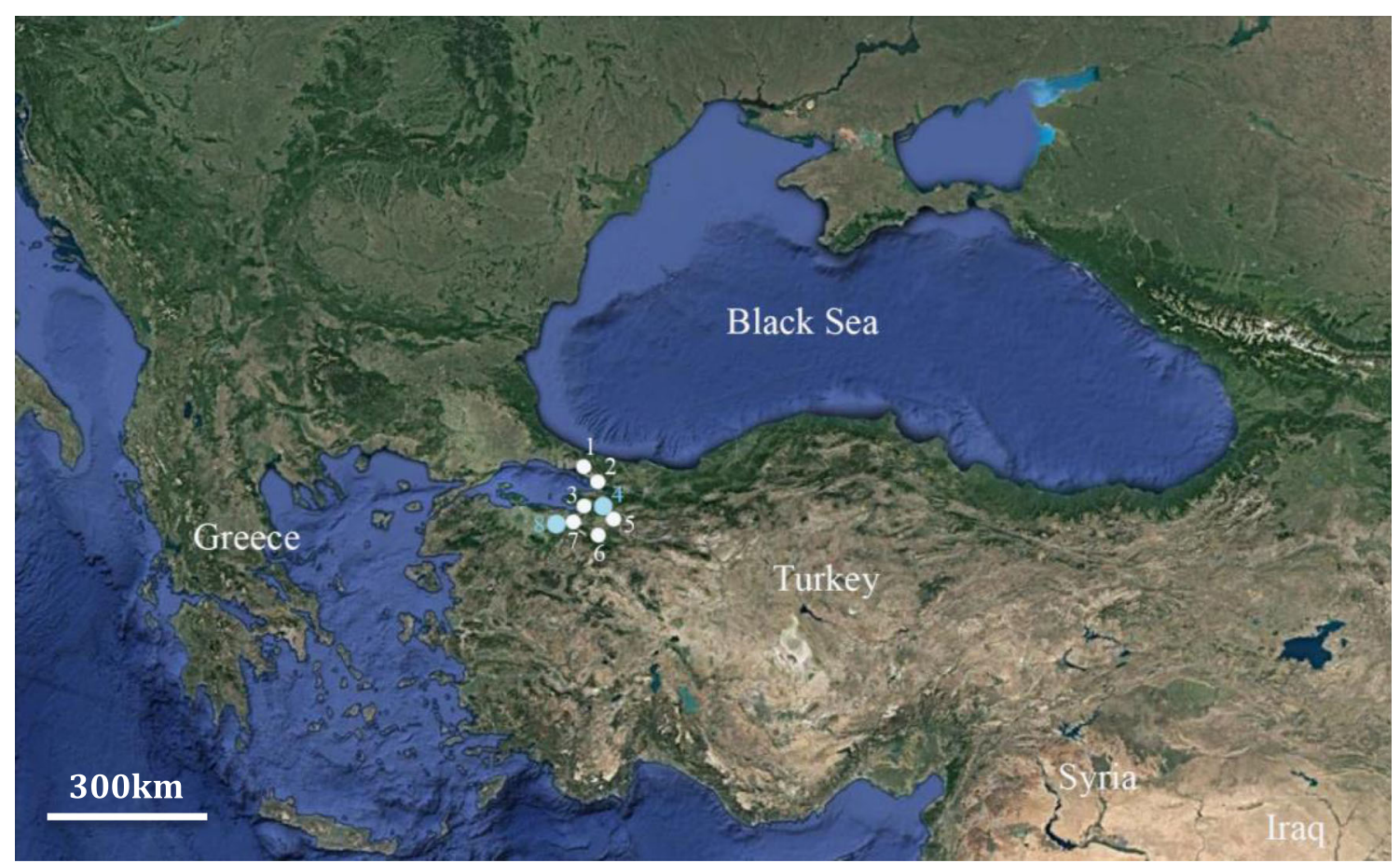

Fig. 1 Map of the study region and sites mentioned in the text. 1 Fikirtepe. 2 Pendik. 3 Ilıpınar. 4 Lake İznik. 5 Barcın Höyük. 6 Menteșe. 7 Aktopraklık. 8 Lake Uluabat (map: Google Earth)

dates from Menteşe (Roodenberg and Alpaslan-Roodenberg 2008).

Areas B and C at Aktopraklık (which form the basis of this study) comprise settlement and cemetery areas. Approximately 60 burials have been recovered from sites B and $\mathrm{C}$ at Aktopraklık during systematic excavations (Fig. 2). At Aktopraklik B, the dead were placed in a contracted position within pits, with monochrome vessels placed at their head and feet and with ornaments and bone tools as accompanying grave goods (Karul and Avc1 2013). In the cemetery area of Aktopraklık C (and also in the settlement area of Aktopraklık B), Late Neolithic and Early Chalcolithic burials were uncovered. These burials have a range of grave goods, including pottery, limestone beads, a handle of a bone spoon, worked bone tools, and a number of faunal remains placed in direct association (Karul and Avc1 2011).

\section{Environmental setting: climate, plants, and animals}

Anatolia is a region of distinct climatic and environmental differences; the coastal areas are mostly humid, with parts of the western shores never receiving frost, in contrast to the eastern Highlands that can be covered with snow for several months of the year (Van Zeist and Bottema, 1991). Northwest Anatolia is nestled within these extremes, and experiences a warm temperate climate that is home, predominantly, to $\mathrm{C}_{3}$ terrestrial vegetation resistant to cold conditions. Evidence for $\mathrm{C}_{4}$ plant species is present during the study period, but only as limited inclusions in archaeological assemblages (Bottema and Woldring 1995; Bottema et al. 2001; Cappers 2008; Schroedter and Nelle 2015).

Schroedter and Nelle (2015) examined charcoal deposits from Late Neolithic and Early Chalcolithic horizons at Aktopraklık. In the Neolithic phase, the charcoal taxa identified show limited diversity. Quercus dominates the record, with inclusions from Pinus, Rhamnus/Phillyrea, Pistacea, and the Maloidae sp. Small amounts of Fraxinus present in the record suggest moist environments in the open woodlands near to the site. Quercus and Pistacea are indirect climate indicators, as Pistacea does not tolerate strong frost, and Quercus is often interpreted as an indicator for Mediterranean climate conditions. The Chalcolithic is characterized by a diversification of taxa, but deciduous oak (Quercus) still remains dominant. The regular occurrence of hydrophilous taxa suggests a shift to moister conditions during this period. No dramatic changes in climate conditions are evident from the charcoal analysis.

Palaeobotanical research of edible wild and domestic plant species at Aktopraklık is ongoing, and no detailed information regarding the plant species present at the site is available at the time of writing. If we consider the context of the region alongside the previous dietary isotope study of bone collagen at Aktopraklık (Budd et al. 2013), we can reasonably speculate that domestic (and wild) animal species fed predominantly on $\mathrm{C}_{3}$ plant species. The research into animal foddering regimes during the Chalcolithic period at Aktopraklık suggests that they were based primarily on barley, a $\mathrm{C}_{3}$ resource (Karul 
Fig. 2 Plan of Aktopraklık B and Aktopraklik C (source:

Schroedter and Nelle, 2015)

\section{Aktopraklık 2011 Plan}

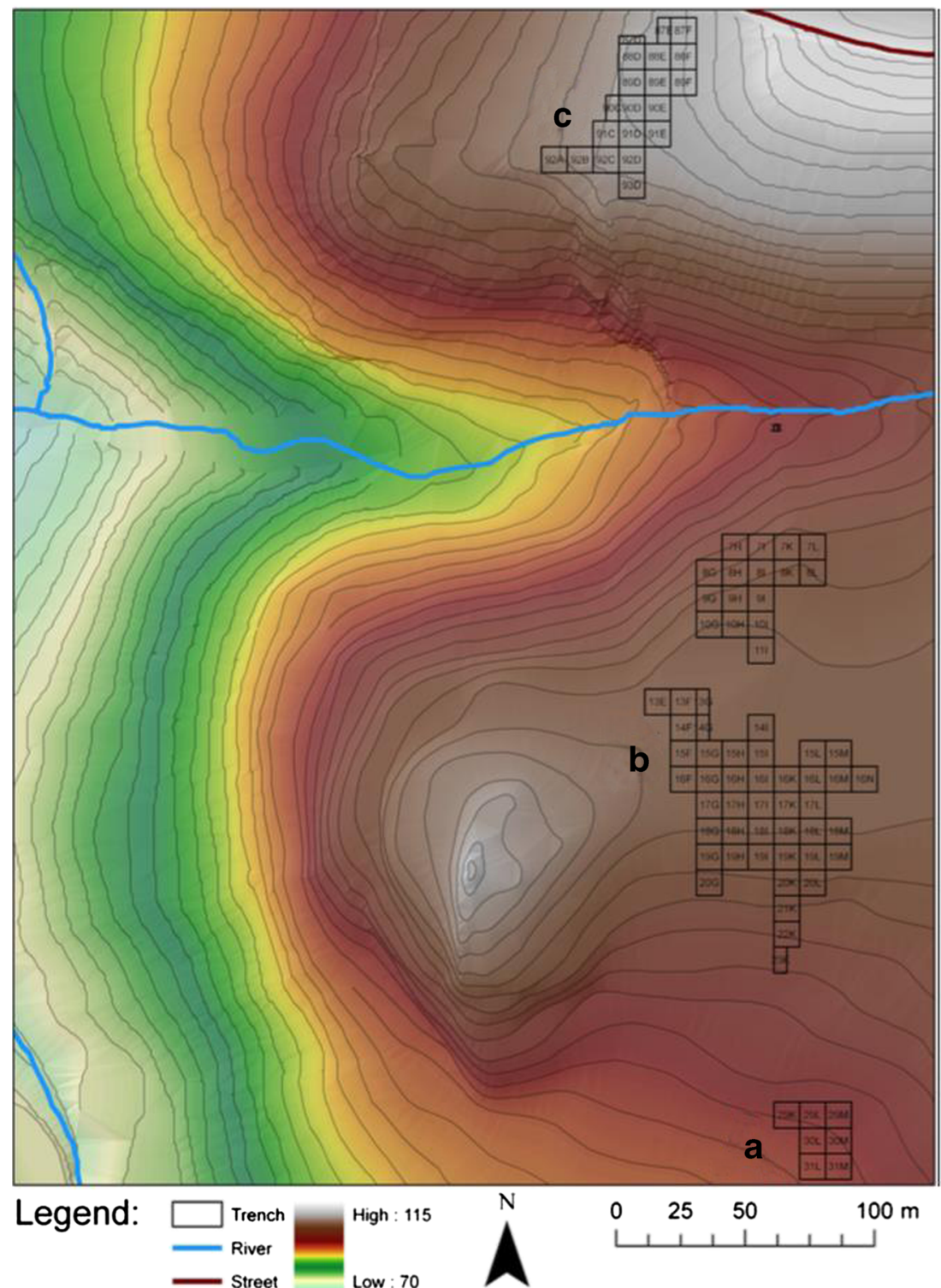

and Avc1 2011). Only one domestic cattle sample from Aktopraklık (AKTH72, Budd et al. 2013), dating to the Early Chalcolithic period, produced a $\delta^{13} \mathrm{C}$ value that suggests significant inclusion of $\mathrm{C}_{4}$ plant species at $-18 \%$ o (see Pearson et al. 2007 for discussion of the $\mathrm{C}_{4}$ consumption boundary). The plant analysis from the contemporary site of Ilipınar is used as an analogue to understand the types of plant species that were available in the region. In addition, $\delta^{13} \mathrm{C}$ data obtained from eight plant samples from Barcın Höyük as part of an AMS dating programme are used to estimate carbon and nitrogen isotope values for plants in the study region (Budd et al. 2017). At Barcın Höyük, the $\delta^{13} \mathrm{C}$ plant data for cereal species $(n=8)$ analysed during the radiocarbon dating programme give an average $\delta^{13} \mathrm{C}$ value of $-23.7 \% \circ \pm 0.9$. A single lentil sample produced a $\delta^{13} \mathrm{C}$ value of $-20.9 \%$. If the human populations at Aktopraklik consumed a diet centred on cereals, based on the isotopic information that we have, we would expect to see human $\delta^{13} \mathrm{C}$ values of ca. $-18.8 \%$, which reflects a 5\%o shift between diet (e.g. living plant tissues) and human bone collagen values. At Ilıpınar, the palaeobotanical evidence supports the exploitation of a range of domesticated plants, including barley, wheat, oats, bitter vetch, lentils (legumes), grass pea, peas, and flax, alongside the domesticated fauna (Cappers 2008). In addition, the charcoal studies at Aktopraklık during the study period suggest an edible carpological component consisting in part of hazel, apple, prunes, and figs (Schroedter and Nelle 2015). By combining multiple strands of evidence, it is reasonable to speculate that 
cereals and wheat species formed a large proportion of the plant assemblage at Aktopraklık with some inclusion of wild fruit species.

The animal assemblage at Aktopraklik is dominated by the presence of domestic species, most notably sheep/goat (Ovis/ Capra sp.) and cattle (Bos taurus). The faunal assemblage is analysed by one of the authors (AG), and further details on species identification, age at death, and distinguishing between wild and domestic species are present in the "Materials and methods" section. The Late Neolithic (6300 $6100 \mathrm{cal} . \mathrm{BC}$ ) animal assemblage at Aktopraklık is characterized by the presence of sheep/goat (57\%) and cattle bones (34\%), with some minor contribution from pigs $(3 \%)$. Fallow deer (4\%) form a larger proportion of the assemblage than domestic pig, although both species are few in number in absolute terms. Other species recovered from the Neolithic deposits at Aktopraklık include Lepus europaeus (European hare), Vulpes vulpes (red fox), Meles meles (European badger), Bos primigenous (auroch), and Canis familiaris (domestic dog). Evidence for a small wild faunal component is largely commensurate with the nearby sites of Barçin Höyük and Illpinar and with sites located further north, such as Fikirtepe, Pendik, and Yenikapı (Buitenhaus 2008; Boessneck and Von den Driesch 1979; Çakirlar 2009).

After the onset of the Chalcolithic period (ca. $5600 \mathrm{cal}$. BC), there is a change in the composition of the faunal assemblage; the percentage of sheep/goat (49\%) decreases in favour of an increasing cattle component (30\%). Pig remains (7\%) also become more prevalent during the Chalcolithic period, although the proportion of fallow deer remains constant (4\%). Overall, there is a marginal shift in the diversity of wild fauna component, with species including L. europaeus (European hare), Cricetus cricetus (European hamster), Ursus arctos (brown bear), Capreolus capreolus (roe deer), and $C$. familiaris (domestic dog). In summary, the faunal assemblage suggests heavy reliance on sheep/goat and cattle resources. Additionally, the zooarchaeological research at Aktopraklık shows continuing and consistent exploitation of fallow deer from the Neolithic into the Chalcolithic period. If the human individuals analysed at Aktopraklık (for this study) were consuming proportionally large quantities of temperate terrestrial resources (e.g. $C_{3}$ plants and the animals that feed on them), we would estimate $\delta^{13} \mathrm{C}$ values of approximately $-19 \%$ \pm 1 and $\delta^{15} \mathrm{~N}$ values of ca. $10 \% \circ \pm 2$ based on the fauna analysed from the first study (Budd et al. 2013).

Today, the site of Aktopraklık is located $3 \mathrm{~km}$ away from Lake Ulubat, and palaeoenvironmental work undertaken in the area has led to the suggestion that during the Neolithic period, the site was located closer to the lake. Despite the site's proximity to both the Marmara Sea and Lake Ulubat, no fish or shellfish remains or, indeed, fishing equipment (e.g. weirs, net sinkers, hooks) have been recovered. In order to fully establish that no fish proteins were consumed during the
Neolithic period, a number of modern reference fish were included in the isotope study, obtained directly from Lake Ulubat. We cannot be certain what species of fish were present in Lake Ulubat during the Neolithic period, and the isotopic values of modern fish species at Lake Ulubat may be influenced by factors such as agricultural pollution, producing results that are not directly comparable with the archaeological samples (Zhen and Zhu 2016; Härberle et al. 2016). However, in the absence of archaeological fish remains, the samples provide an idea of the potential range of $\delta^{13} \mathrm{C}$ values (and $\delta^{15} \mathrm{~N}$ values) from the lake. The carbon and nitrogen isotope values from the modern fish samples are to be interpreted with caution, and used as a general reference point for fish carbon and nitrogen isotope values for Lake Ulubat.

\section{Stable isotope analysis $\left(\delta^{13} \mathrm{C}\right.$ and $\left.\delta^{15} \mathrm{~N}\right)$}

Stable isotope analysis of carbon and nitrogen in bone collagen has proved a useful technique in reconstructing ancient diets. Detailed reviews of the method, its applications, and its limitations are plentiful in the literature (Rundel and Ehleringer 2012; Layman et al. 2012; Boecklen et al. 2011). In simple terms, carbon isotope analysis $\left(\delta^{13} \mathrm{C}\right)$ can allow us to distinguish between dietary protein from marine, terrestrial, and, under some circumstances, freshwater resources (Schwarcz and Schoeninger 1991; Cerling et al. 1997; Richards 2002).

Stable carbon isotope measurement of human and animal bone collagen samples is biased towards the protein component of ingested foods (Schoeninger and DeNiro 1984; Lee-Thorp and Van der Merwe 1987). The composition of local vegetation can also influence the $\delta^{13} \mathrm{C}$ values in a region. Plant species that utilize different photosynthetic pathways, e.g. predominantly $\mathrm{C}_{3}$ (Calvin-Benson) and $\mathrm{C}_{4}$ (Hatch-Slack), produce distinct $\delta^{13} \mathrm{C}$ values (as the pathways discriminate against ${ }^{13} \mathrm{C}$ during photosynthetic fixation of $\mathrm{CO}_{2}$ to a much greater extent in the former than in the latter) (Park and Epstein 1960). In mammalian bone collagen, the isotopic shift between consumer and diet (e.g. $\Delta^{13} \mathrm{C}_{\text {diet-body }}$ ) is ca. 5\%o (DeNiro and Epstein 1978; Casey and Post 2011). Nitrogen stable isotope ratios $\left(\delta^{15} \mathrm{~N}\right)$ are used to establish the trophic level of an organism in the food web, with $\delta^{15} \mathrm{~N}$ enrichment of ca. 3-5\%o (e.g. $\Delta^{15} \mathrm{~N}_{\text {diet-body }}$ ) observed as one progresses up the food chain (Schoeninger and DeNiro 1984; Minagawa and Wada 1984). The 'trophic-level effect' is due to the specific and roughly constant enrichment in ${ }^{15} \mathrm{~N}$ of the consumer's slow turnover body proteins (such as bone collagen) over their diet, for a wide range of mammals, including omnivores (e.g. DeNiro and Epstein 1981; Minagawa and Wada 1984; Sealy et al. 1987). 


\section{Materials and methods}

\section{Recovery and site taphonomy}

Aktopraklık and the surrounding area are covered with olive trees that have caused marked bioturbation of the archaeological layers. Further test pits were excavated prior to systematic excavations of the site to explore the extent of the taphonomic processes in play. A further complicating factor is the building foundations dating to the Byzantine period (Karul and Avci 2011). The foundations start at the south end of the study area and extend in an east-west direction, causing complete destruction to some areas dating to the Neolithic and Chalcolithic. During the Chalcolithic period, Aktopraklık C was used as a cemetery after the settlement shifted to site B. The burials of this cemetery have also caused damaged to the older settlement levels of occupation. Finally, the site is located on limestone bedrock, and the prehistoric levels were preserved in varying depths parallel to the inclination of the virgin soil, leaving the site heavily eroded. Despite the challenges of recovery and interpretation present at the site, the prehistoric deposits are sufficiently preserved to enable research projects.

\section{Zooarchaeology}

Each bone, tooth, or shell specimen is identified taxonomically to species where possible, including the identification of skeletal element and body side. In addition to the use of a reference collection and personal experience (AG), a number of publications were consulted to differentiate between closely related species such as sheep and goat (Boessneck et al. 1964; Halstead and Collins 2002; Zeder and Lapham 2010; Zeder and Pilaar 2010). Besides the morphological criteria, such as the shape and the solidness of bones, bone measurements help to differentiate between wild, pre-domestic, and domesticated animals. The logarithmic size index (LSI method) was applied to reconstruct the size variability of the wild animals and livestock (Meadow 1999); standard comparative individuals include a female auroch (Degerbøl and Fredskild 1970) and a wild sow (Hongo 1998; Hongo and Meadow 2000). The size of each individual animal is reconstructed in accordance with the standard measurement methodology for animal bones (Driesch 1976). The age of an animal is estimated based on eruption patterns and wear stages of their teeth (Payne 1973, 1987; Grant 1982) and the fusion stages of postcranial skeletal elements (Habermehl 1975; Zeder 2006). In order to reconstruct the taphonomic history of the archaeozoological finds, indications for pre- and post-depositional processes like cut marks, traces of burning, rodent and carnivore gnawing, incrustation, and weathering of bones are examined. Factors such as the position of a fragmented bone, as well as the nature of the fractured edges, are recorded to document their breakage pattern.

\section{Anthropological analysis}

The analysis of age and sex of human remains was undertaken by one of us (SAR). Briefly, the majority of burials uncovered at Aktopraklık are single and regular pit graves, suggesting that each pit contained the remains of one individual. Two exceptions are present; one multiple burial (89E-9) included three individuals and another burial contained two individuals (89D AKT 17.1 and 14.1) (Alpaslan-Roodenberg 2011). Aside from a few male skeletons, the overall preservation of human remains was poor, with delicate bones such as pelvis, vertebrae, and costae often fragmented into small pieces. As a consequence of the underlying geology (e.g. limestone bedrock), the skeletal remains were frequently covered with a calcerous deposit (a stone-hard coating) that could not be easily removed, and this often made analysis of the bones challenging.

The human remains were analysed following the methods given by Buikstra and Ubelaker (1994). Morphological traits of the cranium and the pelvis were considered to determine the sex of the adults (Acsádi and Nemeskéri 1970). When pelvic bones were absent, which happened often, the estimate of sex was based on cranial features. In case both pelvic and cranial characteristics were not available, the degree of robustness was considered to determine the sex. Due to poor preservation of most skeletons in this collection, the age at death of adults had to be determined by observations of dental molar wear pattern (Brothwell 1981). The age at death is classified into three groups: young (17-25 years), middle age (25-35 years), and old (35-45 years and older).

\section{Stable isotopes}

Carbon and nitrogen isotope analysis of human and animal bone collagen was undertaken at the Light Stable Isotope Laboratory at Oxford University. The collagen was extracted using a modified version of the Longin (1971) method, using acid and $\mathrm{H}_{2} \mathrm{O}$ (Milli-Q) washes, freeze-drying, and isotope measurement on an elemental analyser linked to a continuous-flow Sercon dual-inlet mass spectrometer. Modern fish samples were subject to 1:1 chloroform methanol to remove extraneous fat from the bone. Known-value standards are included in order to calibrate (and drift correct) the readings taken from the unknown (bone) samples. Isotopic ratios are calculated with reference to in-house standards, which for this project is alanine, USGS-40, and IAEA-C6. $\delta^{13} \mathrm{C}$ measurements are reported on the VPDB scale, and $\delta^{15} \mathrm{~N}$ is reported with reference to AIR.

Quality control parameters are used in stable isotope analysis to ensure the accuracy of the data produced; these include 
a collagen yield of $1 \%$ or above, a $\mathrm{C} / \mathrm{N}$ ratio of between 2.9 and 3.6, and a collagen yield of $5 \mathrm{mg}$ (DeNiro and Epstein 1978; Brock et al. 2010). The $\% \mathrm{C}$ and $\% \mathrm{~N}$ of the collagen samples are also calculated as these provide a reliable indicator of sample preservation (Ambrose 1990; Van Klinken, 1999; Sealy et al. 2014). For bone collagen, the ideal range for $\% \mathrm{C}$ is ca. $40-48 \%$ and for $\% \mathrm{~N}$ is approximately ca. 12 $17 \%$ - it should be noted that these ranges are approximate, with the individual studies (e.g. Ambrose 1990; Van Klinken 1999; Sealy et al. 2014) producing slightly different ranges. The purpose of these parameters is to ensure that sufficient organic material (e.g. mainly collagenous protein) was preserved and that this material retains an acceptable in vivo signal (as assessed by the $\mathrm{C} / \mathrm{N}$ and collagen yield). Statistical analyses were performed in the open source statistics package R (http://www.r-project.org/).

\section{Stable isotope results: fauna and fish}

In total, 30 faunal samples were processed from the Late Neolithic/Chalcolithic site of Aktopraklık, including sheep/ goat, cattle, domestic pig, wild boar, red deer, and fallow deer species. Five modern fish samples were also analysed from Lake Uluabat. Two samples (both sheep/goat) initially failed the quality control parameters due to insufficient collagen yield. These bones were re-sampled and subjected to pre-treatment, and subsequently passed the quality control parameters. Due to the ongoing nature of the excavations at Aktopraklık, fauna has only been excavated and identified to species level (with the exception of sheep/goat remains) from Aktopraklık C. This fauna isotope dataset will be used as a baseline to compare the adult isotope values from Aktopraklık B and C. Ideally, we would isotopically examine fauna from Aktopraklik B alongside the fauna isotope data from Aktopraklık C. However, as Aktopraklık B and C are less than $150 \mathrm{~m}$ apart, it is unlikely that the environments between the two sites were extremely different. If an isotopic difference were present in the faunal remains, we would most likely expect to see this isotope difference present in the human isotope dataset. Mean isotope values are reported in the text to one standard deviation.

Table 1 shows the summary statistics for fauna and fish isotope values from the site (see $\mathrm{S} 1$ for individual isotope datum points). Table 2 provides the individual data points for the human isotope values analysed from Aktopraklık (see S2 for summary statistics of the human data). The average $\delta^{13} \mathrm{C}$ value for the domestic and wild fauna is $-20.2 \% \circ \pm 0.7$, which is representative of the consumption of predominantly $\mathrm{C}_{3}$ terrestrial resources. The wild pig, red deer, and fallow deer samples $(n=4)$ provide a useful baseline for the natural landscape surrounding Aktopraklık (although the small sample size warrants caution). The wild fauna $\delta^{13} \mathrm{C}$ values average at $-20.7 \% \circ \pm 1$ and the $\delta^{15} \mathrm{~N}$ values at $4.3 \pm 0.6 \%$, reflecting the consumption of $\mathrm{C}_{3}$ grasses. These wild fauna values suggest that vegetation in the study area would have $\delta^{13} \mathrm{C}$ values in the region of $-25 \%$ and $\delta^{15} \mathrm{~N}$ values in the region of $1.5 \%$.

The sheep/goat, cattle, and domestic pig $\delta^{13} \mathrm{C}$ and $\delta^{15} \mathrm{~N}$ values $\left(\delta^{13} \mathrm{C}\right.$ average $=-20.2 \% 0 \pm 0.7, \delta^{15} \mathrm{~N}$ average $=6 \% \pm \pm 1.1$ ) have relatively homogenous distributions. The domestic fauna isotope values are not dissimilar to the wild fauna, with the majority of animals showing the consumption of $\mathrm{C}_{3}$ resources. One cattle sample has a $\delta^{13} \mathrm{C}$ value of $-18 \%$, which suggests the inclusion of $\mathrm{C}_{4}$ plant species for this individual (using $-18 \%$ os the suggested baseline for $\mathrm{C}_{4}$ consumption, see Pearson et al. 2007). The fish species analysed produced variable $\delta^{13} \mathrm{C}$ and $\delta^{15} \mathrm{~N}$ values and so are listed separately (Table 2, see $\mathrm{S} 2$ for further information).

The fish species analysed for this study (Esox masquinongy [muskellunge], Cyprinus carpio [yellow carp], Scardinius erythrophthalmus [common rudd], Atherinidae sp. [atherina], and Silurus glanis [wels catfish]) have very depleted $\delta^{13} \mathrm{C}$ values, $-23.5 \% \circ \pm 2.1$, with the $\delta^{15} \mathrm{~N}$ values averaging at $11.8 \% \circ \pm 2.3$. Whilst the modern fish isotope values are concordant with bone collagen in select isotope studies concerning prehistoric fish samples (such as the Ukraine (Lillie et al. 2009, 2013)), it is not possible to elucidate in this study whether anthropogenic factors have influenced the modern fish values.

\section{Statistical testing: fauna}

Kruskal-Wallis testing was performed on the fauna data to investigate whether the variation in isotope values is homogenous (Table 3). This test integrates the fauna isotope data detailed in this paper and also the dataset published by Budd et al. (2013) (see S3 for the original dataset). The aim of the testing is to investigate differences between the isotopic distributions of the fauna species as a novel method for examining the possibility of different animal feeding practices between species at the site. Variation is tested rather than central tendencies (such as means and standard deviation), as a measure of variation will highlight the extent of different patterns between individuals in the group (where group equates to domestic or wild).

Kruskal-Wallis tests are applied to possible permutations of the datasets to see if the results are comparable. Four groups were utilized for the variance tests: cattle, sheep/goat, pig, and wild fauna (wild boar, red deer, and fallow deer). The sample sizes for the wild fauna group and pig are admittedly limited. The 'wild fauna' group is an applicable analogue for the domestic fauna, as deer species are ruminants, like cattle and sheep/goat, and wild boar are non-ruminants, like domestic pigs. The results (Table 3 ) highlight that only the $\delta^{15} \mathrm{~N}$ values of both domestic and wild fauna were approaching a significant difference $(p=0.063)$, with the remaining testing 
Table 1 Summary statistics for all adult fauna and modern fish $\delta^{13} \mathrm{C}$ and $\delta^{15} \mathrm{~N}$ values at Aktopraklık $\mathrm{C}$

\begin{tabular}{lllllllll}
\hline Species & Number & $\delta^{13} \mathrm{C} \min$ & $\delta^{13} \mathrm{C} \max$ & $\delta^{13} \mathrm{C}$ ave & \pm & $\delta^{15} \mathrm{~N} \min$ & $\delta^{15} \mathrm{~N} \max$ & $\delta^{15} \mathrm{~N}$ ave \\
\hline Cattle & 8 & -20.5 & -18.0 & -19.8 & 1.0 & 5.0 & 8.8 & 6.5 \\
Sheep/goat & 13 & -20.9 & -19.2 & -20.1 & 0.6 & 4.8 & 7.8 & 5.9 \\
Pig & 4 & -20.6 & -19.6 & -20.1 & 0.5 & 4.0 & 8.1 & 6.3 \\
Wild boar & 1 & - & - & -19.5 & - & - & - & 2.0 \\
Red deer & 2 & -21.5 & -21.5 & -21.5 & 0 & 4.6 & 5.0 & 4.5 \\
Fallow deer & 1 & - & - & -20.1 & - & - & - & 4.8 \\
Modern fish & 5 & -26.0 & -21.2 & -23.5 & 2.1 & 11.8 & 14.1 & 0.1 \\
\hline
\end{tabular}

showing uniformity in values. No differences are observed between the isotopic distributions of the domestic fauna.

\section{Stable isotope results: humans}

In total, 24 adult human samples were processed (for this study), in addition to 4 sub-adults (Table 4). One human sample failed the quality control parameters, producing a poor $\mathrm{C} /$ $\mathrm{N}$ ratio. This individual was re-sampled and subjected to pretreatment, and subsequently passed the quality control parameter. Figure 3 shows these data integrated alongside the isotope data from Budd et al. (2013) (human total $n=44$ ).

The adult human $\delta^{13} \mathrm{C}$ isotope data, for both Aktopraklık B and Aktopraklik C, average at $-20.2 \%$ \pm 0.3 , with the nitrogen isotope data also showing relative homogeneity at $9.2 \% \circ \pm 0.7$ (Table 5). If we compare the human and faunal $\delta^{13} \mathrm{C}$ and $\delta^{15} \mathrm{~N}$ values, the isotope data suggest a major reliance on terrestrial proteins, a combination of animals and $\mathrm{C}_{3}$ plant species. The average human nitrogen isotope values (ca. 9\%o) suggest a diet that was proportionally higher in domestic animal proteins than plant proteins. If the human populations were consuming high proportions of plant protein, we would anticipate human $\delta^{15} \mathrm{~N}$ closer to ca. $6 \%$. Using the isotope data analysed from the modern fish, the $\delta^{13} \mathrm{C}$ and $\delta^{15} \mathrm{~N}$ values suggest that freshwater (fish) resources did not comprise a large proportion of the diet. It is apparent from Fig. 3 that the human values are more constrained than the associated fauna, which in part reflects the fact that adult human bone collagen reflects a longer-term averaged diet (e.g. over a period of ca. 10 years), whereas domestic animals are often killed

Table 2 Modern fish $\delta^{13} \mathrm{C}$ and $\delta^{15} \mathrm{~N}$ results from Lake Uluabat

\begin{tabular}{llr}
\hline Species & $\delta^{13} \mathrm{C}$ & $\delta^{15} \mathrm{~N}$ \\
\hline Esox masquinongy & -25.2 & 11.2 \\
Cyprinus carpio & -26 & 13.9 \\
Scardinius erythrophthalmus & -23.6 & 11.1 \\
Atherinidae sp. & -21.2 & 10.3 \\
Silurus glanis & -21.7 & 8.6 \\
\hline
\end{tabular}

when still immature, thus reflecting a shorter period of diet and potentially introducing greater inter-animal variation.

\section{Statistical testing: human data}

Table 6 shows the statistic testing for all humans (this study and Budd et al. 2013), at Aktopraklik B $(n=13)$ and Aktopraklık C $(n=30)$. Mann-Whitney $U$ tests $($ alpha $=0.05)$ were undertaken on the human isotope data (chosen over the $t$ test as the residuals of the dataset were not normally distributed). The tests examined overall differences between site (e.g. Aktopraklık B and Aktopraklık C) and intra- and intersite level sex differences.

The tests revealed no isotopic evidence for dietary difference by site or by sex. It should be noted that the securely sexed individuals from Aktopraklık B are too few in number (males $=3$ and females $=4$; the osteological examination of the burials mentioned here are not yet complete) to undertake a reliable test and thus are omitted from the table. Aktopraklik $\mathrm{C}$ has 13 securely sexed males and 12 securely sexed females (Alpaslan Roodenberg 2011).

\section{Discussion}

Human diet at Aktopraklık in northwest Anatolia shows remarkable isotopic consistency between sites $\mathrm{B}$ and $\mathrm{C}$ and between sex of the individuals, with domestic animal proteins forming the largest proportion of the diet. There is variation among burial

Table 3 ANOVA and Kruskal-Wallis statistical test on Aktopraklık fauna isotope values

\begin{tabular}{lll}
\hline Isotope and group & \multicolumn{2}{l}{ Kruskal-Wallis } \\
\cline { 2 - 3 } & $p$ value & KW chi-squared value $(H)$ \\
\hline$\delta^{13} \mathrm{C}$ all fauna & 0.3901 & 3.01 \\
$\delta^{15} \mathrm{~N}$ all fauna & 0.0626 & 7.31 \\
$\delta^{13} \mathrm{C}$ domestic fauna & 0.2579 & 2.71 \\
$\delta^{15} \mathrm{~N}$ domestic fauna & 0.788 & 0.5 \\
\hline
\end{tabular}


Table 4 Individual human $\delta^{13} \mathrm{C}$ and $\delta^{15} \mathrm{~N}$ isotope values (this study)

\begin{tabular}{|c|c|c|c|c|c|c|c|}
\hline Burial ID & Period $^{\mathrm{a}}$ & Dates & Age & Sex & $\delta^{13} \mathrm{C}$ & $\delta^{15} \mathrm{~N}$ & Site \\
\hline 89d16.1 & Late Neolithic & $6300-6100 \mathrm{cal} . \mathrm{BC}$ & 25-35 years & $\mathrm{F}$ & -19.9 & 9.5 & $\mathrm{C}$ \\
\hline $19 \mathrm{~K} 35.1$ & Early Chalcolithic & $5600-5700$ cal. BC & Middle aged & M & -19.8 & 9.9 & $\mathrm{~B}$ \\
\hline $89 \mathrm{~F} 5$ & Early Chalcolithic & $5600-5800$ cal. BC & Mid-old & $\mathrm{F}$ & -20.2 & 8.4 & $\mathrm{C}$ \\
\hline 16G12.1 & Early Chalcolithic & $5600-5800$ cal. BC & $25-35$ years & $?$ & -20.6 & 7.7 & $\mathrm{~B}$ \\
\hline $89 \mathrm{E} 17$ & Early Chalcolithic & $5600-5700$ cal. BC & $50-70$ years & M & -20.1 & 10.6 & $\mathrm{C}$ \\
\hline 89E21 & Early Chalcolithic & $5600-5700$ cal. BC & Adult & M & -20.4 & 8.5 & $\mathrm{C}$ \\
\hline 87E6 & Early Chalcolithic & $5600-5700$ cal. BC & $12-14$ years & - & -20.2 & 9.1 & $\mathrm{C}$ \\
\hline $19 \mathrm{~K} 42.1$ & Early Chalcolithic & $5600-5700$ cal. BC & Child & - & -20.2 & 8.1 & $\mathrm{~B}$ \\
\hline 92D 101 & Early Chalcolithic & $5600-5700$ cal. BC & Adult & M? & -20.1 & 8.4 & $\mathrm{C}$ \\
\hline 90 E.13 & Early Chalcolithic & $5600-5800$ cal. BC & Old adult & $?$ & -20.5 & 9.5 & $\mathrm{C}$ \\
\hline 88D 106 & Early Chalcolithic & $5600-5800$ cal. BC & Middle aged & $\mathrm{F}$ & -20.2 & 9.9 & $\mathrm{C}$ \\
\hline 90E16 & Early Chalcolithic & $5600-5800$ cal. BC & Mid-old & $\mathrm{F}$ & -19.8 & 9.9 & $\mathrm{C}$ \\
\hline $14 \mathrm{~F} 6.47$ & Early Chalcolithic & $5600-5800$ cal. BC & Adult & $?$ & -20.0 & 9.6 & B \\
\hline 92D102a & Early Chalcolithic & $5600-5800$ cal. BC & Young adult & $\mathrm{F}$ ? & -19.7 & 10.1 & $\mathrm{C}$ \\
\hline 92D102b & Early Chalcolithic & $5600-5800$ cal. BC & Middle aged & $\mathrm{M} ?$ & -20.3 & 8.8 & $\mathrm{C}$ \\
\hline $89 \mathrm{~F} 6$ & Early Chalcolithic & $5600-5800$ cal. BC & Adult & M? & -20.3 & 9.1 & $\mathrm{C}$ \\
\hline $88 \mathrm{~F} 15.1$ & Early Chalcolithic & $5600-5800$ cal. BC & Adult & $\mathrm{M} ?$ & -20.1 & 9.9 & $\mathrm{C}$ \\
\hline 90E.6 & Early Chalcolithic & $5600-5800$ cal. BC & Old & $\mathrm{F} ?$ & -20.2 & 8.8 & $\mathrm{C}$ \\
\hline $89 \mathrm{~F} 21.1$ & Early Chalcolithic & $5600-5800$ cal. BC & Middle aged & $\mathrm{F} ?$ & -20.2 & 8.5 & $\mathrm{C}$ \\
\hline $19 \mathrm{~K} 67$ & Early Chalcolithic & $5600-5700$ cal. BC & Old & $\mathrm{F} ?$ & -20.4 & 8.9 & $\mathrm{~B}$ \\
\hline 22K17 & Early Chalcolithic & $5600-5800$ cal. BC & Adult & $?$ & -20.3 & 8.8 & B \\
\hline $88 \mathrm{E} 22$ & Late Neolithic/Early Chalcolithic & $6300-5600$ cal. BC & Adult & $?$ & -19.6 & 10.3 & $\mathrm{C}$ \\
\hline $19 \mathrm{~K} 33.3$ & Early Chalcolithic & $5600-5700$ cal. BC & 4 years old & - & -19.9 & 9.7 & B \\
\hline $19 \mathrm{~K} 87$ & Early Chalcolithic & $5600-5700$ cal. BC & Child & - & -19.4 & 12.1 & B \\
\hline
\end{tabular}

${ }^{a}$ Chronological period is assigned using stratigraphy and material finds by one of us (NK)

rites at Aktopraklık in terms of orientation and grave good inclusion. Approximately half of the individuals were deposited in an east-west position, with the remaining burials displaying all possible orientations (e.g. WE, NS, SN). Individuals were often

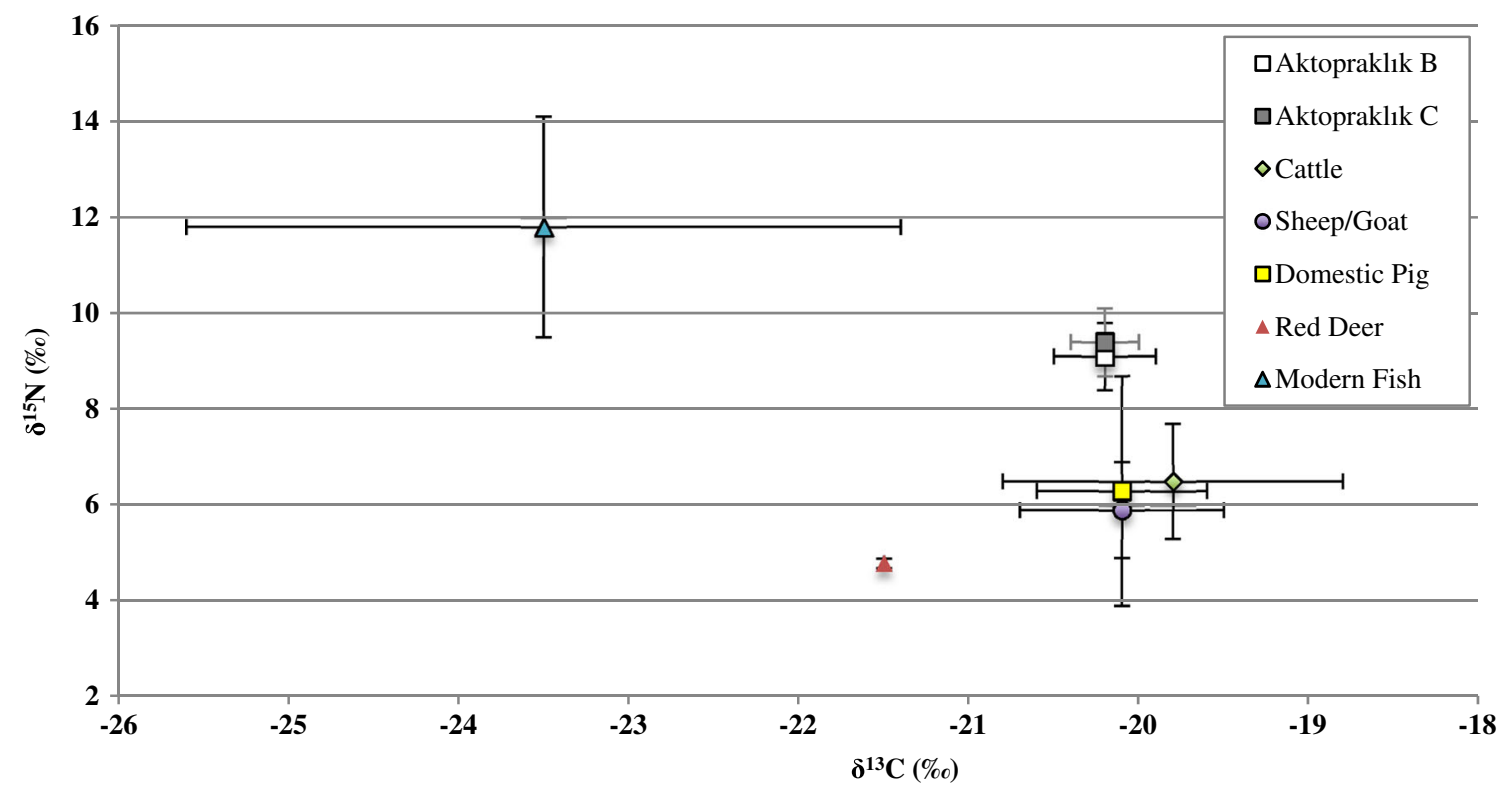

Fig. $3 \delta^{13} \mathrm{C}$ and $\delta^{15} \mathrm{~N}$ average values for all human, fauna, and fish from Aktopraklik (sources: this paper and Budd et al. 2013). Aktopraklık B and Aktopraklık $\mathrm{C}$ refer to adult and non-nursing human isotope values only 
Table 5 Summary statistics for all adult (and non-nursing) human $\delta^{13} \mathrm{C}$ and $\delta^{15} \mathrm{~N}$ isotope values at Aktopraklık

\begin{tabular}{lllll}
\hline Aktopraklık site & $\delta^{13} \mathrm{C}$ average & \pm & $\delta^{15} \mathrm{~N}$ average & \pm \\
\hline B & -20.2 & 0.3 & 9.1 & 0.7 \\
C & -20.2 & 0.2 & 9.4 & 0.7 \\
\hline
\end{tabular}

Sources: this study and Budd et al. (2013)

interred with items, such as sheep/goat bones, bone tools, big stones, limestone beads, and pottery, but select individuals were buried with no grave goods. Overall, there is no obvious patterning in burial rites, by period, sex, or age. However, the skeletal remains experience varying levels of preservation across the site, and in some cases, age and sex information could not be securely identified (Roodenberg 2011). The burials were broadly divided into orientation groups and also into grave good 'types' (e.g. bone tool, stones, beads, pottery), to investigate possible relationships between burial rites and isotope values. No significant patterns were identified.

The cattle $\delta^{13} \mathrm{C}$ data show a similar distribution to the wild fauna $(-19.8 \% \circ \pm 1.0)$. This suggests either that the cattle were grazing on similar $\mathrm{C}_{3}$ species to the wild fauna or that the single enriched cattle value $(-18 \%$ ) originated from an isotopically distinct area. Two of domestic pig samples have noticeably enriched $\delta^{15} \mathrm{~N}$ values (7.2 and 8.1\%o), which potentially reflect the misidentification of juvenile samples and the possibility of pigs browsing on middens or may tentatively suggest import of livestock from nearby contemporary sites. There is no evidence for change in either $\delta^{13} \mathrm{C}$ or $\delta^{15} \mathrm{~N}$ between the areas. Equally, no differences are observed between the domestic fauna. It is plausible that all of the animal species were managed in the same way-e.g. all kept on the same type (isotopically) of grassland, leading to no isotopic differences between species.

Due to the ongoing nature of excavations at Aktopraklik, the available evidence for plant processing to date is limited. The palaeobotanical evidence from contemporary sites (predominantly Ilıpınar, but also Barcın Höyük) suggests that cultivated cereals and wheat formed the major component of plant resources (Cappers 2008). The human stable isotope data from Aktopraklik (this study and Budd et al. 2013) suggest that it is domestic animal proteins - rather than plant proteins - that formed the mainstay of human diet. However, in the absence of available plant samples from the Neolithic and Chalcolithic layers at Aktopraklık for carbon and nitrogen isotope analysis, it is not possible to rule out the impact of manure on isotope signatures (e.g. enriched $\delta^{15} \mathrm{~N}$ values) at the site (see Bogaard et al. 2007).

Despite its possible proximity to a sizeable lake, there is no isotopic or archaeological evidence for the consumption of freshwater fish. The fish $\delta^{13} \mathrm{C}$ values vary by approximately $6 \%$, which reflects the different feeding areas and trophic levels present within a lake (e.g. deep water feeders have more depleted $\delta^{13} \mathrm{C}$ values than species feeding at higher levels, and carnivores will differ due to predation on other species) (Fuller et al. 2012; Dufour et al. 1999; Mackay et al. 2013). The fish $\delta^{15} \mathrm{~N}$ values average at $11.8 \% \circ \pm 2.3$, and are commensurate with known values for freshwater lake systems, and the Atherina value reflects the fact that it is an opportunistic feeding species, which has a preference for zooplankton, but will resort to benthic organisms as a secondary food source (Bartulović et al. 2004). Previous $\delta^{13} \mathrm{C}$ and $\delta^{15} \mathrm{~N}$ and gut investigation studies into modern-day Atherina species have highlighted a discrepancy between the conclusions drawn from the analysis of the gut and from isotope studies, suggesting differences between the assimilated nutrients and the diet that are ingested (Vizzini and Mazzola, 2002). The $\delta^{13} \mathrm{C}$ values of the modern fish samples from Lake Ulubat are generally depleted (e.g. -26 to $-21 \%$ ) in comparison to the fauna $\delta^{13} \mathrm{C}$ values from the site, perhaps with the exception of the red deer samples that are similarly depleted when compared to the catfish and atherina fish samples. The $\delta^{15} \mathrm{~N}$ values from the modern fish species at Lake Uluabat are considerably more elevated than their faunal counterparts (whether domestic or wild), at ca. 9-14\%o-if fish protein had contributed significantly to diet at the site, we would expect human $\delta^{15} \mathrm{~N}$ values of approximately $12 \%$ and higher (up to ca. 17\%o) (using the modern fish isotope values as an analogue). The absence of a freshwater contribution to the diet appears to be in direct contrast to the data (including fishing hooks and significant amounts of fish skeletal remains) from a number of contemporary Neolithic sites to the north of Aktopraklik, such as Fikirtepe and Pendik (Boessneck and Driesch 1979: 51).

In the wider context of northwest Anatolia during the study period, it is clear from recent evidence that (i) cultivated
Table 6 Mann-Whitney $U$ test results for human $\delta^{13} \mathrm{C}$ and $\delta^{15} \mathrm{~N}$ at Aktopraklık B and Aktopraklık $\mathrm{C}$

\begin{tabular}{lll}
\hline Isotope and group & Sex & Mann-Whitney $U$ test \\
\hline$\delta^{13} \mathrm{C}$ Aktopraklık B vs. Aktopraklık C & Combined & $p=0.6672$ \\
$\delta^{15} \mathrm{~N}$ Aktopraklık B vs. Aktopraklık C & Combined & $p=0.17106$ \\
$\delta^{13} \mathrm{C}$ Aktopraklık B vs. Aktopraklık C & M vs. F & $p=0.4956$ \\
$\delta^{15} \mathrm{~N}$ Aktopraklık B vs. Aktopraklık C & M vs. F & $p=0.68916$ \\
$\delta^{13} \mathrm{C}$ Aktopraklık C & M vs. F & $p=0.2113$ \\
$\delta^{15} \mathrm{~N}$ Aktopraklık C & M vs. F & $p=0.41222$ \\
\hline
\end{tabular}


cereals, legumes, and domestic animals were present since the very beginning of the Neolithic, (ii) pigs were not domesticated in the earliest phases of the Neolithic, and (iii) animal husbandry was of key significance to the economy for the entire region (Arbuckle et al. 2014; Peters et al. 2017). Comparing the results of Aktopraklik to this regional framework, we can identify from the zooarchaeological remains that domestic animal species, specifically cattle and sheep/goat, played a key economic role, with the isotope analyses confirming that this contribution was consistent and stable during the Late Neolithic and Early Chalcolithic periods. Wild and domestic pig remains are present from the Late Neolithic phase (ca. 6400-6000 cal. BC) at Aktopraklık albeit in very limited quantity and increase in frequency by the Early Chalcolithic, which is in keeping with the latest interpretive framework for the region (Peters et al. 2017).

\section{Conclusion}

In conclusion, the isotope studies show remarkable uniformity at Aktopraklık. There are no isotope differences evident between the human burials at Aktopraklık B and Aktopraklık C and no isotopic differences evident between the sexes (at the inter- or intra-site level). The dietary isotope study suggests that human diet centred primarily on the exploitation of domestic animals, with smaller contributions from domestic (and/ or wild) $\mathrm{C}_{3}$ plant species. Further analysis of the botanical assemblage from the site is warranted to investigate the role of plants in more detail. There is no isotopic evidence to suggest the ingestion of aquatic resources in any great quantities.

Open Access This article is distributed under the terms of the Creative Commons Attribution 4.0 International License (http:// creativecommons.org/licenses/by/4.0/), which permits unrestricted use, distribution, and reproduction in any medium, provided you give appropriate credit to the original author(s) and the source, provide a link to the Creative Commons license, and indicate if changes were made.

\section{References}

Acsádi, G. and Nemeskéri, J. 1970. History of human life span and mortality. Akadémiai Kiadó

Alpaslan Roodenberg S (2011) A preliminary study of the burials from Late Neolithic-Early Chalcolithic Aktopraklık. Anatolica XXXVII: $17-43$

Ambrose SH (1990) Preparation and characterization of bone and tooth collagen for isotopic analysis. J Archaeol Sci 17:431-451

Arbuckle BS, Atici L (2013) Initial diversity in sheep and goat management in Neolithic south-western Asia. Levant 45(2):219-235

Arbuckle BS, Kansa SW, Kansa E, Orton D, Çakirlar C, Gourichon L, Atici L, Galik A, Marciniak A, Mulville J, Buitenhaus H, Carruthers D et al (2014) Data sharing reveals complexity in the westward spread of domestic animals across Neolithic Turkey. PLoS One 9(9):e107824. doi:10.1371/journal.pone.0107824
Boecklen WJ, Yarnes CT, Cook BA, James AC (2011) On the use of stable isotopes in trophic ecology. Annu Rev Ecol Evol Syst 42: $411-440$

Boessneck J, Müller HH, Teichert M (1964) Osteologische Unterscheidungsmerkmale zwischen Schaf (Oivs aries L) und Ziege (Capra hircus L.) Kühn-Archiv 78:1-129

Boessneck J, Von den Driesch A (1979). Die Tierknochenfunde aus der neolithischen Siedlung auf dem Fikirtepe bei Kadiköy am Marmarameer. Universität München, Institut für Palaeoanatomie, Domestikationsforschung und Geschichte der Tiermedizin

Bottema S, Woldring H (1995) The environment of classical Sagalassos: a palynological investigation. Sagalassos III:327

Bottema S, Woldring H (2001) The Late Quaternary vegetation history of western Turkey. In: Kayan I (ed) The Ilıpınar excavations II. Nederlands Instituut Voor Het Nabije Oosten, Leiden

Brock F, Higham T, Ramsey CB (2010) Pre-screening techniques for identification of samples suitable for radiocarbon dating of poorly preserved bones. J Archaeol Sci 37:855-865

Brothwell, D.R. (1981) Digging up bones. Cornell University Press

Budd CE, Lillie MC, Alpaslan-Roodernberg S, Karul N, Pinhasi R (2013) Stable isotope analysis of Neolithic and Chalcolithic populations from Aktopraklık, northern Anatolia. J Archaeol Sci 40(2):860-867

Budd CE, Gerritsen F, Alpaslan Roodenberg S, Schulting R, Galik A, Lillie M (2017) Early Farmers in northwest Turkey: Stable carbon and nitrogen isotope bone collagen studies of human diet at Neolithic Barcın Höyük. Archaeometry (in press)

Buikstra, J.E. and Ubelaker, D.H. (1994) Standards for data collection from human skeletal remains: proceedings of a seminar at the Field Museum of Natural History. Arkansas Archeol Surv

Buitenhaus H (2008) Ilipinar: the faunal remains from the late Neolithic and early Chalcolithic levels. Travaux de la Maison de l'Orient et de la Méditerranée 49(1):299-322

Çakirlar, C (2009) Mollusk shells in Troia, Yenibademli, and Ulucak: an archaeomalacological approach to the environment and economy of the Aegean. J \& E Hedges

Çakirlar, C. (2014). Molluscs (invertebrates): analyses in environmental Archaeology. In: Encyclopedia of global archaeology. Springer: 5005-5010

Çakirlar C (2015) Adaptation, identity, and innovation in Neolithic and Chalcolithic Western Anatolia (6800-3000 cal. BC): the evidence from aquatic mollusk shells. Quat Int 390:117-125

Cappers R (2008) Plant remains from the Late Neolithic and Early Chalcolithic levels. Life and death in a prehistoric Settlement in Northwest Analtolia. Ilıpınar Excavations 3:117-148

Casey MM, Post DM (2011) The problem of isotopic baseline: reconstructing the diet and trophic position of fossil animals. Earth-Sci Rev 106:131-148

Cerling TE, Harris JM, MacFadden BJ, Leakey MG, Quade J, Eisenmann V, Ehleringer JR (1997) Global vegetation change through the Miocene/Pliocene boundary. Nature 389:153-158

Degerbøl M, Fredskild B (1970) The urus (Bos primigenius BOJANUS) and Neolithic domesticated cattle (Bos taurus LINN.) in Denmark. Det Kongelige Dansk Videnskabernes Selskab. Biologiske Skrifter 17:1-177

DeNiro MJ, Epstein S (1978) Influence of diet on the distribution of carbon isotopes in animals. Geochim Cosmochim Acta 42:495-506

DeNiro MJ, Epstein S (1981) Influence of diet on the distribution of nitrogen isotopes in animals. Geochim Cosmochim Acta 45:341351

Çilingiroğlu Ç, Çakırlar C (2013) Towards configuring the neolithisation of Aegean Turkey. Documenta Praehistorica 40(2013):21-29

Dufour E, Bocherens H, Mariotti A (1999) Palaeodietary implications of isotopic variability in Eurasian lacustrine fish. J Archaeol Sci 26(6): $617-627$

Emre Ö, Kazancı N, Erkal T, Karabıyıkoglu M, Kușçu I (1997) Formation and geological evolution of lakes Ulubat ve Manyas. 
In: Neogene and Quaternary evolution of southern Marmara Region. A project report for Turkish Scientific and Research Council (TUBITAK), YDABCAG-426/G, Ankara, 116-134 (in Turkish)

Evershed RP, Payne S, Sherratt AG, Copley MS, Coolidge J, Urem-Kotsu D, Kotsakis K, Özdoğan M, Özdoğan AE, Nieuwenhuyse O, Akkermans PMMG, Bailey D, Andeescu R-R, Campbell S, Farid S, Hodder I, Yalman N, Özbașaran M, Bıçakcı E, Garfinkel Y, Levy T, Burton MM (2008) Earliest date for milk use in the Near East and southeastern Europe linked to cattle herding. Nature 455(7212):528531

Fuller BT, Müldner G, Van Neer W, Ervynck A, Richards MP (2012) Carbon and nitrogen stable isotope ratio analysis of freshwater, brackish and marine fish from Belgian archaeological sites (1st and 2nd millennium AD). J Anal At Spectrom 27(5):807-820

Grant A (1982) The use of tooth wear as a guide to the age of domestic ungulates. In: Wilson, B. Grigson C. Payne S. Ageing and sexing animal bones from archaeological sites. BAR Br Ser 109:91-108

Habermehl K-H (1975) Die Altersbestimmung bei Haus- und Labortieren, 2. Auflage edn. Parey, Berlin

Halstead P, Collins P (2002) Sorting sheep from goats: morphological distinctions between the mandibles and mandibular teeth of adult Ovis and Capra. J Archaeol Sci:545-553

Hongo H (1998) Patterns of animal husbandry in central Anatolia in the second and first millenia BC: faunal remains from KamanKalehöyük, Turkey. In: Buitenhuis, H. Bartosiewicz L. Choyke A. M. Archaeolzoology of the Near East III. Proceedings of the third international symposium on the southwestern Asia and adjacent areas. ARC Publicaties 18:255-275

Hongo H, Meadow RH (2000) Faunal remains from Prepottery Neolithic levels at Canöyü, southeastern Turkey: a preliminary report focusing on pigs (Sus sp.). In: Mashkour, M. Choyke A. M. Buitenhuis H. Poplin F. Archaeozooloy of the Near East IV A. ARC Publicatie 32: 121-139

Karul, N. (2007) Aktopraklık 2004-2006 Yılı Çalıșmaları Genel Bir Değerlendirme. [Field Report]

Karul, N. (2011). The emergence of Neolithic life in south and east Marmara region. Beginnings New Research in the Appearance of the Neolithic between Northwest Anatolia and the Carpathian Basin. Papers of the International Workshop, $8^{\text {th }}-9^{\text {th }}$ April 2009, Istanbul

Karul N, Avc1 MB (2011) Neolithic communities in the eastern Marmara region: Aktopraklık C. Anatolica XXXVII:1-15

Karul N, Avcı MB (2013) Aktopraklık. In: Özdoğan M, Başgelen N, Kuniholm P (eds) The Neolithic in Turkey, Vol. 5. Northwestern Turkey and Istanbul. New excavations \& new research. Archaeology \& Art Publications, Istanbul, pp 45-68

Kazanc1 N, Leroy S, Ileri Ö, Emre Ö, Kibar M, Öncel S (2004) Late Holocene erosion in NW Anatolia from sediments of Lake Manyas, Lake Ulubat and the southern shelf of the Marmara Sea, Turkey. Catena 57(3):277-308

Kazancı N, Toprak Ö, Leroy S, Öncel S, Ileri Ö, Emre Ö, Costa P, Erturac K, McGee E (2006) Boron content of Lake Ulubat sediment: a key to interpret the morphological history of NW Anatolia, Turkey. Appl Geochem 21(1):134-151

Layman CA, Araujo MS, Boucek R, Hammerschlag-Peyer CM, Harrison E, Jud ZR, Matich P, Rosenblatt AE, Vaudo JJ, Yeager LA et al (2012) Applying stable isotopes to examine food-web structure: an overview of analytical tools. Biol Rev 87(3):545-562

Lazaridis I, Patterson N, Mittnik A, Renaud G, Mallick S et al (2014) Ancient human genomes suggest three ancestral populations for present-day Europeans. Nature 513(7518):409-413

Lee-Thorp J, Van der Merwe NJ (1987) Carbon isotope analysis of fossil bone apatite. S Afr J Sci 83:712-715

Leroy SAG, Kazanc1 N, Ileri Ö, Kibar M, Emre O, McGee E, Griffiths HI (2002) Abrupt environmental changes within a late Holocene lacustrine sequence south of the Marmara Sea (Lake Manyas, N-W Turkey). Mar Geol 190:531-552
Longin R (1971) New method of collagen extraction for radiocarbon dating. Nature 230:241-242

Mackay AW, Bezrukova EV, Boyle JF, Holmes JA, Panizzo VN, Piotrowska N, Shchetnikov A, Shilland EM, Tarasov P, White D (2013) Multiproxy evidence for abrupt climate change impacts on terrestrial and freshwater ecosystems in the Ol'khon region of Lake Baikal, central Asia. Quat Int 290:46-56

Mathieson I, Lazaridis I, Rohland N, Mallick S, Patterson N, Alpaslan Roodenberg S et al (2015) Genome-wide patterns of selection in 230 ancient Eurasians. Nature 528:499-503. doi:10.1038/nature 16152

Meadow RH (1999) The use of size index scaling techniques for research on archaeozoological collections from the Middle East. In: Becker C, Manhart H, Peters J, Schibler J (eds) Historia Animalium ex Ossibus: Beiträge aur Paläoanatomie, Archäologie, Ägyptologie, Ethnologie und Geschichte der Tiermedizin. Verlag Marie Leidorf, Rahden/Westfalen, pp 285-300

Minagawa M, Wada E (1984) Stepwise enrichment of ${ }^{15} \mathrm{~N}$ along food chains: further evidence and the relation between $\delta^{15} \mathrm{~N}$ and animal age. Geochim Cosmochim Acta 48:1135-1140

Park R, Epstein S (1960) Carbon isotope fractionation during photosynthesis. Geochim Cosmochim Acta 21:110-126

Payne S (1973) Kill-off patterns in sheep and goats: the mandibles from Asvan Kale. Anatol Stud 23:281-303

Payne S (1987) Reference codes for wear states in the mandibular cheek teeth of sheep and goats. J Archaeol Sci 14:609-614

Pearson JA, Buitenhuis H, Hedges REM, Martin L, Russell N, Twiss KC (2007) New light on early caprine herding strategies from isotope analysis: a case study from Neolithic Anatolia. J Archaeol Sci 34: 2170-2179

Peters, J.A., Schmidt, K., Dietrich, O. and N. Pöllath. (2014). Göbekli Tepe: agriculture and domestication. Encyclopedia of Global Archaeology, Springer: 3065-3068

Peters JA, Pöllath N, Arbuckle BS (2017) The emergence of livestock husbandry in early Neolithic Anatolia. In: Albarella U, Rizzetto M, Russ H, Vickers K, Viner-Daniels S (eds) The Oxford handbook of zooarchaeology. OUP, Oxford

Richards MP (2002) A brief review of the archaeological evidence for Palaeolithic and Neolithic subsistence. Eur J Clin Nutr 56:12

Roodenberg J (2016) Neolithic farmers from the eastern Marmara region on the move - closing the circle? Anatolica XLII:1-10

Roodenberg J and Alpaslan-Roodenberg S (2008) Ilıpınar and Menteșe: early settlement in the eastern Marmara region. Living Well Together: 8-27

Rundel P and Ehleringer JR (2012) Stable isotopes in ecological research 68. Springer and Business Link

Schoeninger MJ, DeNiro MJ (1984) Nitrogen and carbon isotopic composition of bone collagen from marine and terrestrial animals. Geochim Cosmochim Acta 48:625-639

Schroedter TM, Nelle O (2015) New insights into Mid-Holocene vegetation in the southern Marmara region: charcoal from the Late Neolithic to Early Chalcolithic settlement site Aktopraklık, northwestern Turkey. Quat Int 366:81-95

Schwarcz HP, Schoeninger MJ (1991) Stable isotope analyses in human nutritional ecology. Am J Phys Anthropol 34:283-321

Sealy JC, Johnson M, Richards M, Nehlich O (2014) Comparison of two methods of extracting bone collagen for stable carbon and nitrogen isotope analysis: comparing whole bone demineralization with gelatinization and ultrafiltration. J Archaeol Sci 47:64-69

Sealy JC, van der Merwe NJ, Thorp JAL, Lanham JL (1987) Nitrogen isotopic ecology in southern Africa: Implications for environmental and dietary tracing. Geochim Cosmochim Acta 51(10):2707-2717

Thissen L, Özbal H, Bıyık AT, Gerritsen FG, Özbal R (2010). The Land of Milk? Approaching Dietary Preferences or Late Neolithic Communities in NW Anatolia. Anatolia. Leiden J Pott Stud 26: $157-172$ 
Türkekul-Bıyık A, Özbal H (2008) Arkeolojik Çanak ve Çömleklerde Organik Kalıntıların Belirenmesi: Anadolu'dan Bazı Örnekler. In: Arkeometri Sonuçları Toplantıs1, vol. 23, pp. 249e264

Van Klinken GJ (1999) Bone collagen quality indicators for palaeodietary and radiocarbon measurements. J Archaeol Sci 26:687-695

Van Zeist W, Bottema S (1991) Plant husbandry in Early Neolithic Nea Nikomedeia, Greece. Acta botanica neerlandica 20(5):524-538

Vigne J-D, Briois F, Zazzo A, Willcox G, Cucchi T et al (2012) First wave of cultivators spread to Cyprus at least 10,600 y ago. Proc Natl Acad Sci 109(22):8445-8449

Vizzini S, Mazzola A (2002) Stable carbon and nitrogen ratios in the sand smelt from a Mediterranean coastal area: feeding habits and effect of season and size. J Fish Biol 60(6):1498-1510

von den Driesch, A. (1976) Das Vermessen von Tierknochen aus vorund frühgeschichtlichen Siedlungen. München
Zeder MA (2006) Reconciling rates of long bone fusion and tooth eruption and wear in sheep (Ovis) and goat (Capra). In: Ruscillo D (ed) Recent advances in ageing and sexing animal bones. Oxbow Press, Oxford, pp 87-118

Zeder MA (2011) The origins of agriculture in the Near East. Curr Anthropol 52(S4):S221-S235

Zeder MA, Lapham HA (2010) Assessing the reliability of criteria used to identify postcranial bones in sheep, Ovis, and goats, Capra. J Archaeol Sci 37(11):2887-2905

Zeder MA, Pilaar SE (2010) Assessing the reliability of criteria used to identify mandibles and mandibular teeth in sheep, Ovis, and goats, Capra. J Archaeol Sci 37:225-242

Zhen S, Zhu W (2016) Analysis of isotope tracing of domestic sewage sources in Taihu Lake - a case study of Meiliang Bay and Gonghu Bay. Ecol Indic 66:113-120 